Keio J. Med. 24: 311-334, 1975

\title{
STUDIES ON LYMPHOCYTE SUBPOPULATIONS AND THEIR RESPONSES TO MITOGENIC STIMULATIONS OF MYASTHENIC PATIENTS
}

\author{
SHIGERU ARIMORI*, YASUNARI NAKATA*, SHINYA TADA, \\ HIDEHIRO KOBASHI, YUKINOBU ICHIKAWA* \\ and KENJI KORIYAMA*
}

Division of Immunology, Department of Internal Medicine (The Second), Okayama University Medical School, Okayama, Japan 700

* Address: Department of Internal Medicine (The Fourth), School of Medicine, Tokai University, Bohseidai, Isehara-shi, Japan, 259-11

\begin{abstract}
The lymphocyte subpopulations, T- and B-lymphocytes, and their responses to mitogenic stimulations in the peripheral blood, the bone marrow, and the thymus were analysed in the patients with myasthenia gravis.

The lymphocytes were isolated on 'Ficoll-Conray 400 ' gradient. The Tlymphocytes were identified by the sheep red blood cell-rosette-formation, and the B-lymphocytes by the surface immunoglobulin. The responses of lymphocytes to PHA.P and PWM stimulations were also studied in vitro using ${ }^{3} \mathrm{H}$-thymidine as indicator with the same lymphocyte lots in part of these samples.

The mean value of the circulating T-lymphocytes among 11 healthy subjects tested was $1503 \pm 342 / \mathrm{cmm}(\mathrm{M} \pm \mathrm{SD})$, whereas B-lymphocytes was $584 \pm 133 / \mathrm{cmm}$.

Decreased T-lymphocyte and B-lymphocyte with lower responsiveness to mitogens, especially to PHA-P, were characteristic in myasthenia gravis indicating the abnormality of $\mathrm{T}$-cell function. The extirpation of the thymus, either thymoma and/or non-thymomatous thymus with "B-cell origin lymphfollicle", induced the normalization of these lymphocytes dysfunction. The administration of immunosuppressants affected on the lymphocytes as same effect of thymectomy. Including the lymphocytes of the patients with systemic lupus erythematosus, these lymphocytes deficiency was in proportion to the severity of clinical symptoms. Local T- and B-lymphocyte identification using $\mathrm{E}$ and $\mathrm{EAC}$ on the cryosections indicated that a major portion of lymphorrhage in the skeletal muscle of myasthenic patients was B-lymphocytes. The pathognomonic significancy of cellular immune deficiency and anti-membrane antibody was discussed.
\end{abstract}




\section{INTRODUCTION}

The myasthenia gravis has been considered to be immunological disorders due to high presence of anti-muscle striation antibody, higher presence of antinuclear antibody, lower complement level, therapeutic responses to thymectomy and association with other disease of presumed autoimmune diseases such as rheumatoid arthritis and systemic lupus erythematosus. ${ }^{13,17}$ It has been believed, however, that the electrophysiological blocking in the neuromuscular junction of skeletal muscle of myasthenic patients could not be verified by the reaction of circulating antibody in local.

On the other hand, we recently found the anti-motor endplate antibody in the sera of myasthenic patients in vitro ${ }^{7}$ and in vivo ${ }^{8}$ as well as the anti-muscle membrane antibody.4,5

The author demonstrated previously the cytotoxic effects of the myasthenic lymphocytes as showed by the development of runt disease in young mice, ${ }^{14}$ and the destruction of motor endplate in combination with muscle fiber of the tibialis anterior muscle of the rats. ${ }^{15}$

Further investigations of the myasthenic lymphocytes are presented in this paper, studying the lymphocyte subpopulations, T- and B-lymphocytes, and their responses to mitogenic stimulations in the peripheral blood, the bone marrow, and the thymus.

\section{MATERIALS AND METHODS}

Clinical material. Twenty seven cases of healthy subjects ranging in age from 18 to 47 year-old provided the peripheral blood lymphocytes used in this studies. The myasthenic patients were derived from the out-patient and inpatient populations of the Second Department of Internal Medicine,

during 1971 to 1974. The diagnosis and the classification were performed according to the clinical symptoms, electromyography including Tensilon test and the pneumomediastinography. The thymectomy of these patients were performed with mid-sternum approach in a case of hyperplastic thymus, being revealed by pneumomediastinography, and with costal approach in a case of thymoma at the Second Department of Surgery,

The thymus and the thymoma were completely removed except one case of malignant thymoma.

Total myasthenic patients observed in this study were 54 cases. These were 32 cases whose thymus were hyperplastic in 22 cases and thymomatous in 10 cases. The thymectomized patients were 22 cases. 14 cases had pathologically 
verified hyperplastic thymus without thymoma at surgery. 8 cases were proved to have lymphoepithelial thymoma at operation. Eleven patients including thymomatous cases were followed their lymphocyte subpopulations through thymectomy

For the control study 11 normal subjects and 13 cases of polymyositis, 17 systemic lupus erythematosus, 5 progressive systemic screlosis, 7 Hashimoto's disease, 13 Sjögren's syndrome, 8 Behçet's disease, 8 rheumatoid arthritis, 3 ulcerative colitis and 2 periarteritis nodosa were also observed in their peripheral blood.

Preparation of lymphocyte. Heparinized peripheral blood and bone marrow aspirates were added aseptically with 3 volume and 15 volume of saline respectively. With aseptic precautions, the thymus, spleen, and lymph node were sliced for $1 \mathrm{~mm}$ in thickness in the Hank's balanced salt solution. The cells were squeezed out of these sliced tissues by passing through No. 18 nylon mesh. The cells were placed on the mixture of $33.4 \%$ Conray 400 (Daiichi Ph. Co. Tokyo, Japan) and 9\% Ficoll 400 (Pharmacia Fine Chem. Uppsala, Sweden) solution $(10: 24, \mathrm{~V} / \mathrm{V})$, and were centrifugated at $400 \mathrm{~g}$ for $30 \mathrm{~min}$. The lymphocytes fraction was washed once with saline, three times with gelatine-veronal buffered saline (GVB).

Identification of T-cells (Rosette-forming cells; RFC). Sheep erythrocytes (E) (The Japan Biotest Research Institute, Tokyo, Japan) were washed with saline three times, and lymphocytes were suspended in fetal calf serum (Grand Island Biological Com. Grand Island, N.Y.), and were adjusted in the cell counts to $5.0 \times 10^{6}$ and $1.0 \times 10^{8}$ per $1 \mathrm{ml}$. The mixture of lymphocytes and $\mathrm{E}$ with equal volume was incubated at $37^{\circ} \mathrm{C}$ for $15 \mathrm{~min}$. followed by the centrifugation at $300 \mathrm{~g}$ for $5 \mathrm{~min}$. After the incubation at $0^{\circ} \mathrm{C}$ for $60 \mathrm{~min}$., the mixture was resuspended and was mounted on the slide glass. The lymphocytes binding the $\mathrm{E}$ more than two were counted in the 200 lymphocvtes as RFC under a Nikon phase contrast microscope with DLL $100 \times 10$ magnification.

Identification of B-cell (Surface immunoglobulin-bearing cells; SIBC). The lymphocytes were resuspended in a final concentration of $2 \times 10^{5}$ per $1 \mathrm{ml}$ of TCM 199. They were incubated with FITC conjugated anti-human IgG, IgA and $\operatorname{IgM}$ gout sera, separately, at $0^{\circ} \mathrm{C}$ for $30 \mathrm{~min}$., and were washed three times with $0.02 \mathrm{M}$ phosphate buffered saline (PBS) ( $\mathrm{pH}$ 7.4). Resuspended lymphocytes bearing specific surface membrane fluorescence in the glycerol-phosphate buffered saline were observed as SIBC in the 200 lymphocytes under a Nikon fluoromicroscope with the filters of $\mathrm{BO}$ and UO. Percent of SIBC was calculated adding the percentages of each class of surface immunoglobulin-bearing cells.

Mitogen-induced lymphocyte stimulation index (PHA-S.I. and PWM-S.I.). 
Aseptic lymphocytes in a final concentration of $0.5 \times 10^{6}$ cells per $1 \mathrm{ml}$ were cultured in TCM 199 containing 15 per cent fetal-calf serum and $15 \mu \mathrm{g}$ of phytohemagglutinin-P (Difco Lab. Detroit, Michigan), or $15 \mu \mathrm{g}$ pokeweed mitogen (Grand Island Biological Com. Grand Island, N.Y.) under $5 \% \mathrm{CO}_{2}$ incubator for 68 hours. After the incubation of lymphocyte suspensions with $1 \mu \mathrm{C}$ (specific activity $5.0 \mathrm{c} / \mathrm{mM}$ ) ${ }^{3} \mathrm{H}$-thymidine for 4 hours, the lymphocytes were collected on the surface of a Millipore filter Type HA $0.45 \mu$ (Millipore Corp., Bedford. Mass.) washed by adding saline followed by 5\% TCA and dried completely. The Millipore filter with lymphocytes was floated in the scintillation vial contained $10 \mathrm{ml}$ scintillator consisted with $4.0 \mathrm{~g}$ PPO and $50 \mathrm{mg}$ POPOP (Packard Inst. Co., Downers Grove. Ill.) in $1000 \mathrm{ml}$ toluene. The ${ }^{3} \mathrm{H}$-thymidine incorporation was counted automatically by the Shimazu liquid scintillation counter.

The stimulation index (S.I.) was calculated as

$$
\text { S.I. }=\frac{\mathrm{cpm} \text { of PHA or PWM added culture }}{\mathrm{cpm} \text { of mitogen non-added culture (soloculture) }} \times 100
$$

although each cpm was the mean value of cpm obtained by triplicated cultures.

Identification of lymphocyte subpopulations in tissue. Washed sheep erythrocyte (E), or antibody (hemolysin) and complement binding $E(E A C)$, or FITC conjugated anti-human immunoglobulin rabbit serum was overlayed on the non-fixed frozen-section. E or EAC binding tissues were observed under the Nikon differential interference microscope (model $\mathrm{T}$ ) as $\mathrm{T}$ or $\mathrm{B}$ cells indicator, respectively. SIBC in tissue was also observed under the Nikon fluoromicroscope using BV excitation.

\section{RESULTS}

The normal values and the data obtained from myasthenic patients were demonstrated in Table 1.

In comparison with healthy subjects, the percentages and the number per $\mathrm{cmm}$ in peripheral blood of myasthenic lymphocytes decreased on both $\mathrm{T}$ and $\mathrm{B}$ cells, especially in B-cells of the thymomatous myasthenic patients $(0.001<\mathrm{p}<0.01$ in percentages and $0.02<\mathrm{p}<0.01$ in cell numbers per $\mathrm{cmm}$ ).

After the thymectomy of non-thymomatous thymus, decreased B-cell augmented their percentage significantly $(\mathrm{p}<0.001)$, been accompaning with a decline in peripheral lymphocyte counts $(0.02<p<0.05)$.

The thymectomized patients whose thymus was revealed to be thymomatous pathohistologically, were followed by normalized T-cells $(p<0.001$ in increase) and B-cells populations. 
Table 1

Summary of the lymphocyte subpopulations and lymphocyte responses to mitogens in vitro in myasthenic patients

\begin{tabular}{lccccc}
\hline & Lym cmm & T-cell $\%$ & T-cell/cmm & B-cell/\% & B-cell/cmm \\
\hline $\begin{array}{l}\text { healthy control } \\
\text { myasthenia gravis }\end{array}$ & $2318 \pm 544(8)$ & $65 \pm 3(11)$ & $1503 \pm 342(11)$ & $27 \pm 4(11)$ & $584 \pm 133(11)$ \\
$\begin{array}{c}\text { non- } \\
\text { thymectomized } \\
\text { pre-thx +non-thx } \\
\text { non-thymomatous }\end{array}$ & $1923 \pm 1076(52)$ & $58 \pm 15(57)$ & $1121 \pm 700(52)$ & $24 \pm 10(54)$ & $509 \pm 382(49)$ \\
$\begin{array}{c}\text { pre-thx } \\
\text { post-thx }\end{array}$ & $1888 \pm 989(64)$ & $57 \pm 16(69)$ & $1068 \pm 648(64)$ & $23 \pm 9(66)$ & $460 \pm 347(61)$ \\
thymomatous & $1818 \pm 752(129)^{*}$ & $58 \pm 17(134)$ & $1053 \pm 547(128)$ & $29 \pm 12(130)$ & $520 \pm 327(129)$ \\
pre-thx & $1866 \pm 1356(17)$ & $47 \pm 17(19)^{*}$ & $952 \pm 742(17)^{*} 21 \pm 8(18)$ & $378 \pm 338(16)$ \\
post-thx & $2072 \pm 1107(50)$ & $61 \pm 15(58)$ & $1175 \pm 709(52)$ & $26 \pm 11(58)$ & $545 \pm 394(52)$ \\
\hline & & & & & \\
\hline
\end{tabular}

Abbreviation: Lym; peripheral lymphocyte counts. T-cell; sheep erythrocyte rosetteforming cell (RFC). B-cell; surface immunoglobulin bearing cell (SIBC). Soloculture; incorporated $\mathrm{cpm}$ of ${ }^{3} \mathrm{H}$-thymidine into cultured lymphocytes in vitro adding no mitogen. PHA-S.I.; stimulation index of lymphocyte culture in vitro with phytohemagglutinin-P as mitogen. PWM-S.I.; stimulation index of lymphocyte culture in vitro with pokeweed mitogen as stimulant. non-thx; non-thymectomized patient, pre-thx; the data obtained before thymectomy of the thymectomized patients, post-thx; the data obtained after thymectomy. parenthesis indicated the number of sample tested. *; comparison of these mean values with those of normal controls by t-test indicated significant differences. ${ }^{* *}$; comparison of these mean values of pre-thx and post-thx in the same group. $p$ values in all instances were less than 0.05 .

The ${ }^{3} \mathrm{H}$-thymidine incorporations in vitro without adding any mitogens (soloculture) into the myasthenic lymphocytes reduced severely at the levels of $49 \%$ of normal value in the non-thymectomized and the non-thymomatous patients, and $10 \%$ in the thymomatous patients, being changed their responses through 


\section{Correlation of RFC \& PHA reactivity in myasthenic lymphocytes}

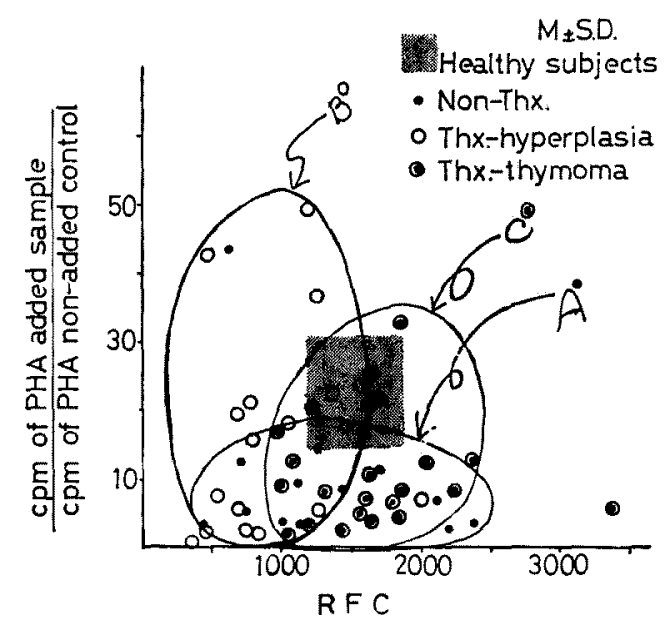

Fig. 1 Correlation of T-cell population and the response to PHA-P stimulation of myasthenic lymphocytes was demonstrated. Myasthenic patients were divided to three groups: A; not-thymectomized patients including thymomatous and non-thymomatous patients, B; thymectomized patients whose thymus was hyperplasia type, i.e. non-thymomatous, C; thymectomized patients whose thymus was thymomatous. A group has lower PHA-responsiveness with wide distribution of T-cell. B group shows lower T-cell with wide distribution of PHA-responsive.ess. C group has normalized T-cell with lower PHA-responsiveness.

the thymectomy into $44 \%$ in the non-thymomatous patients, and $52 \%$ in the thymomatous patients.

The response of myasthenic lymphocytes in vitro against PHA-P stimulation were significantly suppressed in the non-thymectomized patients than healthy lymphocytes $(p<0.02)$. Slight improvement of the lymphocyte response to PHA$\mathbf{P}$ appeared through thymectomy in the group of non-thymomatous myasthenia, although no improvement was noticed in the thymomatous patients.

The lymphocyte response of non-thymectomized patients to pokeweed mitogen was approximately $67 \%$ of healthy lymphocytes, $72 \%$ in the non-thymomatous, $67 \%$ in the thymomatous patients. The thymectomy brought the recovery of lymphocyte reactivities to pokeweed mitogen to the levels of $84 \%$ in the non- 
thymomatous, and $95 \%$ in the thymomatous patients.

The effect of thymectomy on the serum $\gamma$-globulin level was only slight, being higher in the non-thymomatous and lower in the thymomatous myasthenia.

Correlation of T-cell population and the response to PHA-P stimulation of myasthenic lymphocytes was demonstrated in Fig. 1. Only three out of 15 patients $(20 \%)$ of the non-thymectomized hold in the normal zone. In the thymectomized patients, the non-thymomatous beared lower T-cells with higher responses to PHA-P whereas the thymomatous showed higher T-cells with lower responses to PHA-P. Correlation of B-cells and the pokeweed mitogen reactivities of myasthenic lymphocytes also indicated wide abnormal distributions in the non-thymectomized patients as well as in the non-thymomatous and in the thymomatous patients. It was difficult to find out any rules statistically significant in this figure (Fig. 2).

Further analysis according to Osserman's classification in combination with pre- and post-thymectomized patients was attempted in Table 2 . In the nonthymomatous patients non-thymectomized, numbers of T-cell and B-cell decreased remarkably from healthy subjects in type IIb (T-cell; $0,001<p<0.01, B$-cell; $\mathrm{p}<0.001$ ), type IV (T-cell and B-cell; $\mathrm{p}<0.001$ ), and type IIa (T-cell; $0.01<\mathrm{p}<$ 0.02 , B-cell ; $0.02<\mathrm{p}<0.05$ ), while they increased in type $\mathrm{I}$. The thymectomy of non-thymomatous thymus was followed by significantly reduce $\mathrm{T}$-cell $(0.001<\mathrm{p}<$ $0.01)$ and $B$-cell $(0.02<p<0.05)$ in type $I$ in comparing with pre-thymectomy, and by increased T-cell $(0.01<\mathrm{p}<0.02)$ and $\mathrm{B}$-cell $(0.001<\mathrm{p}<0.01)$ in type IV

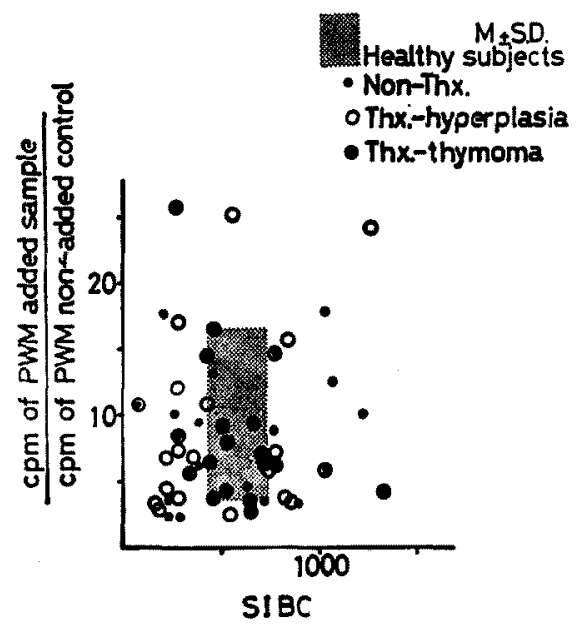

Fig. 2 Correlation of B-cells and the pokeweed mitogen reactivities of myasthenic lymphocytes. 
Table 2

Summary of the lymphocyte subpopulations and lymphocyte responses to mitogens in vitro in the patients with myasthenia gravis whose symptoms were classifed according to the Osserman's classification

\begin{tabular}{|c|c|c|c|c|c|c|c|}
\hline & & $\mathrm{Lym} / \mathrm{cmm}$ & T-cell/\% & \multicolumn{2}{|c|}{$\mathrm{T}$-cell $/ \mathrm{cmm}$} & $\mathrm{B}-\mathrm{cell} / \%$ & B-cell $/ \mathrm{cmm}$ \\
\hline \multicolumn{8}{|c|}{ non-thymomatous } \\
\hline \multirow[t]{2}{*}{ I } & pre-thx & $2397 \pm 1171(21)$ & $56 \pm 14(21)$ & $1362 \pm 77$ & $(21)$ & $25 \pm 12(19)$ & $657 \pm 482(19)$ \\
\hline & post-thx & $* * 988 \pm 318(12) *$ & $57 \pm 23(13)$ & $* * 523 \pm 28$ & $(12)^{*}$ & $32 \pm 16(13) *$ & $* 329 \pm 194(12) *$ \\
\hline \multirow[t]{2}{*}{ IIa } & pre-thx & $1785 \pm 854(29)$ & $58 \pm 18(33)$ & $1018 \pm 57$ & $9(30)^{*}$ & $22 \pm 8(31)$ & $415 \pm 234(29)^{*}$ \\
\hline & post-thx & $2075 \pm 699(62)$ & $58 \pm 18(63)$ & $1186 \pm 53$ & $2(61)$ & $27 \pm 10(61)$ & $562 \pm 325(60)$ \\
\hline \multirow[t]{2}{*}{ IIb } & pre-thx & $1064 \pm 197(2)^{*}$ & $66 \pm 15(3)$ & $655 \pm 9$ & $3(2)^{*}$ & $13 \pm 3(3)$ & $122 \pm 8(2)^{*}$ \\
\hline & post-thx & $1419 \pm 613(25)^{*}$ & $60 \pm 15(25)$ & $851 \pm 42$ & $1(26)^{*}$ & $26 \pm 11(26)$ & $347 \pm 162(26) *$ \\
\hline \multirow[t]{2}{*}{ IV } & pre-thx & $1076 \pm 514(10)^{*}$ & $55 \pm 16(11)$ & $659 \pm 26$ & $3(10) *$ & $23 \pm 9(11)^{*-1}$ & $* 288 \pm 104(10) *$ \\
\hline & \multicolumn{7}{|c|}{ thymomatous } \\
\hline \multirow[t]{2}{*}{ II a } & pre-th $x$ & $2514 \pm 660(6)$ & $64 \pm 10(7)$ & $1582 \pm 38$ & $9(6)$ & $23 \pm 10(7)$ & $599 \pm 363(6)$ \\
\hline & post-thx & ${ }^{*} 1301 \pm 369(3)^{*}$ & $69 \pm 6(3)$ & $891 \pm 20$ & $8(3)^{*}$ & $25 \pm 6(3)$ & $317 \pm 78(3)^{*}$ \\
\hline \multirow[t]{2}{*}{ IIb } & pre-thx & $3075 \pm 862(3)^{*}$ & $45 \pm 4(4)^{*}$ & $1710 \pm 33$ & $5(3)^{*}$ & $28 \pm 12(24)$ & $958 \pm 613(2)^{*}$ \\
\hline & post-thx & $2234 \pm 1010(19)^{* *}$ & ${ }^{*} 67 \pm 13(24)$ & $1460 \pm 62$ & $8(21)$ & $28 \pm 13(24)$ & $635 \pm 465(21)$ \\
\hline \multirow[t]{3}{*}{ III } & pre-thx & $1481 \pm 1140(13)^{*}$ & $46 \pm 19(14)^{*}$ & $780 \pm 73$ & $6(13)^{*}$ & $19 \pm 9(14)^{* *}$ & * $293 \pm 218(13)$ * \\
\hline & post-thx & $2473 \pm 964(21)$ & $59 \pm 14(25)^{*}$ & $* 1445 \pm 63$ & $4(21)$ & $25 \pm 11(24)$ & $631 \pm 301(21)$ \\
\hline & & r-glob. & solocul & $\mathrm{re} / \mathrm{c}$ & $\mathrm{PH}$ & Le. & $\mathrm{PV}$ \\
\hline \multicolumn{8}{|c|}{ non-thymomatous } \\
\hline \multirow[t]{2}{*}{ I } & pre-thx & $1.09 \pm 0.19(16)$ & $1486 \pm 11$ & $73(4)$ & $828 \pm$ & $\pm 470(4)^{*}$ & $723 \pm 450(4)$ \\
\hline & post-thx & $* * 0.83 \pm 0.24(9)$ & & & & & \\
\hline \multirow[t]{2}{*}{ II a } & pre-thx & $1.14 \pm 0.44(23)$ & $1308 \pm 8$ & $344(7)^{*}$ & $1082 \pm$ & $\pm 1369(8)^{*}$ & $887 \pm 637(4)$ \\
\hline & post-thx & $1.16 \pm 0.31(52)$ & $1424 \pm 12$ & $258(12)$ & $1104 \pm$ & $\pm 779(12)^{*}$ & $979 \pm 706(10)$ \\
\hline \multirow[t]{2}{*}{ IIb } & pre-thx & $0.83 \pm 0.22(2)$ & & & & & \\
\hline & post-thx & $1.04 \pm 0.40(15)$ & $1153 \pm 10$ & $49(8) *$ & $1569 \pm$ & $\pm 1593(8)$ & $913 \pm 727(8)$ \\
\hline \multirow[t]{2}{*}{ IV } & pre-thx & $1.34 \pm 0.44(10)$ & $1499 \pm 6$ & $37(6)$ & $670 \pm$ & $\pm 383(7)^{*}$ & $343 \pm 152(5)$ \\
\hline & post-thx & $1.45 \pm 0.57(26)$ & $842 \pm 32$ & $20(5)^{*}$ & $378 \pm$ & $\pm 318(9)^{*}$ & $438 \pm 213(8)$ \\
\hline \multicolumn{8}{|c|}{ thymomatous } \\
\hline \multirow[t]{2}{*}{ IIa } & pre-thx & $0.99 \pm 0.48(7)$ & 1726 & & 66 & & 71 \\
\hline & post-thx & $1.17 \pm 0.05(2)$ & & & & & \\
\hline \multirow[t]{2}{*}{ IIb } & pre-thx & & & & & & \\
\hline & post-thx & $0.96 \pm 0.30(17)$ & $1473 \pm 10$ & $33(10)^{*}$ & $948 \pm$ & $\pm 849(10)^{*}$ & $863 \pm 369(10)$ \\
\hline \multirow[t]{2}{*}{ III } & pre-thx & $1.04 \pm 0.21(11)$ & 279 & & 1633 & & 643 \\
\hline & post-th $x$ & $1.09 \pm 0.31(11)$ & $1467 \pm 18$ & $373(9)$ & $1306 \pm$ & $\pm 849(9) *$ & $946 \pm 792(9)$ \\
\hline
\end{tabular}

Abbreviation: I; type I or ocular type. IIa; type IIa or mild generalized type. IIb; type IIb or generalized type with bulbar signs. III; type III or fulminant type. IV; type IV or late severe type. 
and type IIb. Incorporated $\mathrm{cpm}$ in soloculture was about $50 \%$ normal range $(p<0.05)$, irrespective of the type and the experience of thymectomy, except type IV which showed much lower uptake after thymectomy $(0.01<\mathrm{p}<0.02)$. PHA-S.I. was also lower than healthy one in type IV $(p<0.001)$, type I $(0.001<p<0.01)$, and type IIa $(0.02<\mathrm{p}<0.05)$. Decreased PHA-S.I. through thymectomy was noticed in type IV whose clinical courses of myasthenic symptomes usually aggravated temporarily after thymectomy. PWM-S.I. reduced profoundly in type IV. The peripheral lymphocytes of non-thymectomized patients decreased in type IIb $(0.001<\mathrm{p}<0.01)$, type IV $(\mathrm{p}<0.001)$ and type IIa, in this order. A remarkable drop of the peripheral lymphocyte counts was observed in type $I \quad(p<0.001)$ after the thymectomy, normalization in type IV $(\mathrm{p}<0.001)$ and in type IIa, and slight increase in type IIb. Serum $\gamma$-globulin increased slightly through the thymectomy except type I $(0.001<\mathrm{p}<0.01$ in decrease $)$.

In the myasthenic patients with thymoma, per cent of $\mathrm{T}$-cell decreased in type IIb $(\mathrm{p}<0.001)$ and type III $(0.01<\mathrm{p}<0.02)$, and revised through the thymectomy in type IIb $(0.001<p<0.01)$ and type III. The T-cell numbers were higher in type IIb and lower in type III $(0.001<\mathrm{p}<0.01)$. Both of them were normalized through the thymectomy $(0.001<\mathrm{p}<0.01$ in type III in increase) only exception of type IIa whose T-cell decreased remarkably $(0.02<\mathrm{p}<0.05)$. Concerning on B-cell of the thymomatous patients, decreased per cent $(0.02<\mathrm{p}<$ $0.05)$ and number $(p<0.001)$ in type III, increased number in type IIb $(0.01<$ $\mathrm{p}<0.05$ ) were observed before the thymectomy. Through the thymectomy B-cell in type IIa and type IIb decreased, and in type III increased $(0.001<\mathrm{p}<0.01)$. Studies of stimulation index in vitro of thymomatous myasthenia could not conclude any results because of insufficient data but lower responses in all situations than normal control $(0.02<\mathrm{p}<0.05$ in type IIb post-thx, type III post-thx, and $0.001<\mathrm{p}<0.01$ in type IIb post-thx). The circulating lymphocytes increased in type IIb $(0.001<\mathrm{p}<0.01)$, and decreased in type III $(0.02<\mathrm{p}<0.05)$ before the thymectomy. The thymectomy induced a reduction of lymphocyte counts in type IIa $(0.02<p<0.05)$ and type IIb, and an increase in type III.

The whole changes of the circulating lymphocytes and their subpopulations including the responses to mitogens in vitro were summarized in Fig. 4 extending over the thymectomy in myasthenic patients. Each mean value was compared with the data of healthy subjects.

The circulating lymphocytes decreased significantly at $6(0.02<\mathrm{p}<0.05), 9$, 11 and 15 months $(0.001<\mathrm{p}<0.01)$ after the thymectomy. The T-cell percentages increased at 2 weeks and 4 months $(0.02<\mathrm{p}<0.05)$, and decreased at 21 $(0.01<\mathrm{p}<0.02)$ and 23 months $(\mathrm{p}<0.001)$ after the thymectomy. The T-cell numbers decreased at $5,6,9,11,15$ and 19 months after the thymectomy $(\mathrm{p}<$ 


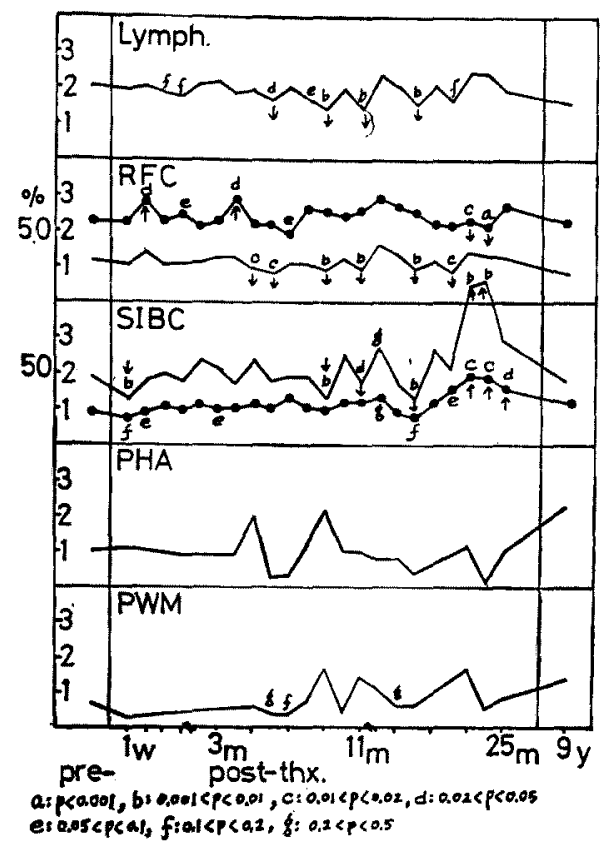

Fig. 3 Follow-up study of lymphocyte subpopulations and their mitogenic reactivities through the thymectomy.

Abbreviation: a; $\mathrm{p}<0.001, \mathrm{~b} ; 0.001<\mathrm{p}<0.01$, c; $0.01<\mathrm{p}<0.02, \mathrm{~d} ; 0.02<\mathrm{p}<0.05$, e; $0.05<\mathrm{p}<0.1$, $\mathrm{f} ; 0.1<\mathrm{p}<0.2, \mathrm{~g} ; 0.2<\mathrm{p}<0.5$ in comparison with those of normal controls by t-test.

0.02). The B-cells decreased at 1 week, 9,11 and 15 months ( 1 week, 9 and 15 months; $0.001<\mathrm{p}<0.01,11$ months; $0.02<\mathrm{p}<0.05)$, been following the increase of both number $(0.001<\mathrm{p}<0.01)$ and percentage $(0.01<\mathrm{p}<0.02)$ at 21 and 23 months after the thymectomy. Incorporated cpm into the soloculture was significantly decreased at 6 and 8 months $(\mathrm{p}<0.05)$ after the thymectomy. The lymphocytes responses to PHA-P stimulations got to be gradually higher in 5 , 9, 21 months to 9 years after the thymectomy with the same tendency of responses to pokeweed mitogen.

The thymectomy was proved to be effective on myasthenic symptomes in almost all patients thymectomized except a part of them whose symtoms, especially bulbar signs, tentatively took a turn for the worse during 1 to 3 years after the thymectomy.

Effectively thymectomized patients showed decreased T-cell numbers with 


\section{Table 8}

The lymphocyte subpopulations and their mitogenic reactivities in the thymectomized patients according to the effectiveness of the thymectomy

\begin{tabular}{|c|c|c|c|c|c|c|}
\hline & $\mathrm{Lym} / \mathrm{cmm}$ & $\mathrm{T}-\operatorname{cell} / \%$ & \multicolumn{2}{|c|}{$\mathrm{T}$-cell/cmm } & B-cell/\% & B-cell/cmm \\
\hline \multicolumn{7}{|l|}{ Effective } \\
\hline pre-thx & $2324 \pm 990(16)$ & $54 \pm 15(19)^{*}$ & \multicolumn{2}{|c|}{$1218 \pm 528(17)$} & $19 \pm 8(18)^{*}$ & * $438 \pm 326(16)$ \\
\hline post-thx & $1896 \pm 815(134)$ & $59 \pm 17(140)$ & \multicolumn{2}{|c|}{$1083 \pm 578(136)$} & $*^{* *} 28 \pm 12(142)$ & $531 \pm 360(131)$ \\
\hline \multicolumn{7}{|c|}{ Tentative worsening } \\
\hline pre-thx & $2275 \pm 782(9)$ & $49 \pm 21(10)^{*}$ & \multicolumn{2}{|c|}{$1190 \pm 644(8)$} & $20 \pm 6(10)$ & $460 \pm 119(9)^{*}$ \\
\hline post-thx & $1822 \pm 1008(45)$ & $58 \pm 15(50)$ & \multicolumn{2}{|c|}{$1180 \pm 661(46)$} & $27 \pm 12(50)$ & $496 \pm 309(46)$ \\
\hline & $\gamma$-glob. & \multicolumn{2}{|c|}{ soloculture/cpm } & \multicolumn{2}{|c|}{ PHA-S.I. } & PWM-S.I. \\
\hline \multicolumn{7}{|l|}{ Effective } \\
\hline pre-thx & $1.31 \pm 0.39(15)$ & \multirow{3}{*}{\multicolumn{2}{|c|}{$1346 \pm 1071(32)^{*}$}} & \multirow{2}{*}{\multicolumn{2}{|c|}{$1098 \pm 1044(33)$}} & \\
\hline post-thx & $1.18 \pm 0.44(107)$ & & & & & $872 \pm 582(31)$ \\
\hline \multicolumn{5}{|c|}{ Tentative worsening } & & \\
\hline pre-thx & $1.04 \pm 0.31(6)$ & \multirow{2}{*}{\multicolumn{2}{|c|}{$\begin{array}{l}830 \pm 702(3)^{*} \\
947 \pm 817(15)^{*}\end{array}$}} & \multicolumn{2}{|c|}{$398 \pm 213(3)$} & $831 \pm 889(3)$ \\
\hline post-thx & $1.02 \pm 0.22(32)$ & & & $762 \pm$ & $685(14)$ & $1274 \pm 1642(12)$ \\
\hline
\end{tabular}

increased B-cell percentage $(p<0.001)$ and number in comparison with those obtained before the thymectomy (Table 3 ). Tentatively worsening group after the thymectomy had a lower T-cell percentage $(0.01<\mathrm{p}<0.02)$, B-cell number $(0.02<\mathrm{p}<0.05)$ and lower cpm incorporation into soloculture $(0.02<\mathrm{p}<0.05)$ with the lowest responses in PHA-P stimulations in comparing with healthy values $(p<0.001)$.

\section{Table 4}

The lymphocyte subpopulations and their mitogenic reactivities in the myasthenic patients according to the effectiveness of the anti-cholinesterase drugs

\begin{tabular}{|c|c|c|c|c|c|}
\hline & $\mathrm{Lym} / \mathrm{cmm}$ & T-cell $/ \%$ & $\mathrm{~T}$-cell $/ \mathrm{cmm}$ & B-cell $/ \%$ & B-cell/cmm \\
\hline non effective & $2013 \pm 969(13)$ & $57 \pm 11(13)^{*}$ & $1185 \pm 717(13)$ & $25 \pm 14(13)$ & $599 \pm 465(13)$ \\
\hline narrow threshold & $1846 \pm 855(74)$ & $58 \pm 17(81)$ & $1067 \pm 574(75)^{*}$ & $28 \pm 12(79)$ & $493 \pm 248(74)$ \\
\hline \multirow[t]{2}{*}{ effective } & $1954 \pm 936(169)$ & $58 \pm 17(186)$ & $1137 \pm 626(172)$ & $26 \pm 11(175)$ & $524 \pm 373(168)$ \\
\hline & $\gamma$-glob. & \multicolumn{2}{|c|}{ soloculture/cpm } & PHA-S.I. & PWM-S.I. \\
\hline non effective & $1.03 \pm 0.19(11)$ & \multicolumn{2}{|c|}{$996 \pm 401(3)$} & $791 \pm 525(3)$ & $1823 \pm 1176(3)$ \\
\hline narrow threshold & $1.01 \pm 0.25(47)$ & \multicolumn{2}{|c|}{$1132 \pm 1338(19)^{*}$} & $1046 \pm 1148(22)^{*}$ & $802 \pm 692(22)$ \\
\hline effective & $1.19 \pm 0.42(140)$ & \multicolumn{2}{|c|}{$1419 \pm 1014(40)^{*}$} & $958 \pm 884(41)$ & $753 \pm 529(34)$ \\
\hline
\end{tabular}


From the view points of effectiveness of anti-ChE drugs on myasthenic symptoms, no significant variations were obtained in each others of non-effective, narrow threshold and effective groups, though narrow threshold group had a lower T-cell number in comparing with healthy subjects $(0.01<p<0.02)$, and non-effective group had the lowest responses to pokeweed mitogen stimulation (Table 4).

The immunosuppressants as azathioprine and prednisolone, were adminis-

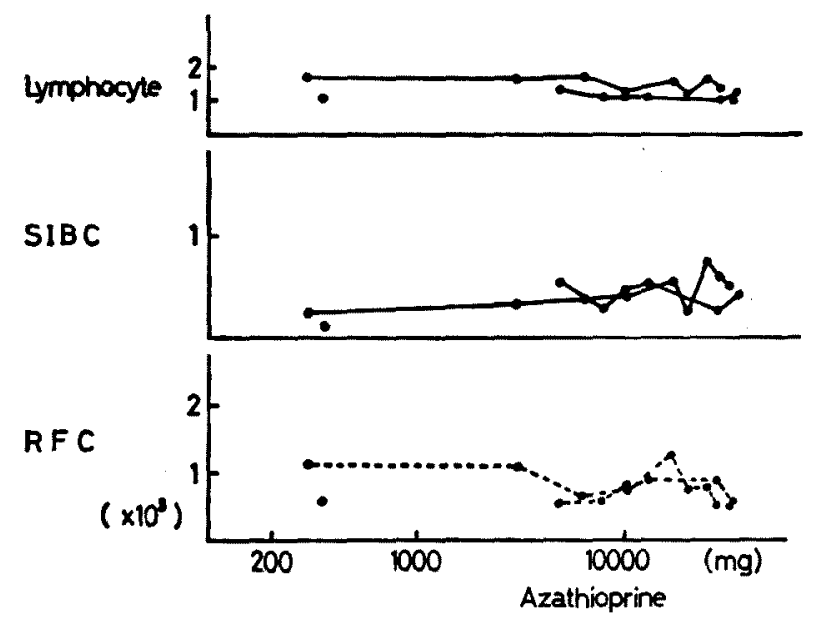

Fig. 4 The effect of accumulative doses of azathioprine on lymphocyte subpopulations.

tered to the myasthenic patients. Azathioprine induced little fluctuations of the circulating lymphocytes, B-cell and T-cell. The circulating lymphocytes hold relatively constant number. The B-cell increased gradually since accumulative dose of azathioprine reached approximately $7000 \mathrm{mg}$ (Fig. 4). On the contrary, T-cell decrease gradually depending on amount of azathioprine. Prednisolone hardly affected on the peripheral lymphocyte counts, though B-cell was generally diminishing and T-cell was augmenting from $500 \mathrm{mg}$ of sum administered, being followed by a final normalization of both subpopulations at the total doses of nearly $2000 \mathrm{mg}$ (Fig. 5).

The T-cell of intrathymic lymphocytes obtained from the myasthenic patients was $67.6 \pm 14.9 \%$, whereas B-cell was $11.0 \pm 14.0 \%$. Less B-cell were found in non-thymomatous thymus (T-cell ; $68.4 \pm 12.9 \%$, B-cell ; $8.9 \pm 10.8 \%$ ), especially whose thymus developed no germinal center, than the thymomatous thymus (T-cell; $68.0 \pm 14.1 \%$, B-cell; $12.2 \pm 16.7 \%$ ). A good correlation was obtained between the circulating T-cell and thymic T-cell in the same individuals (Fig. 6) 

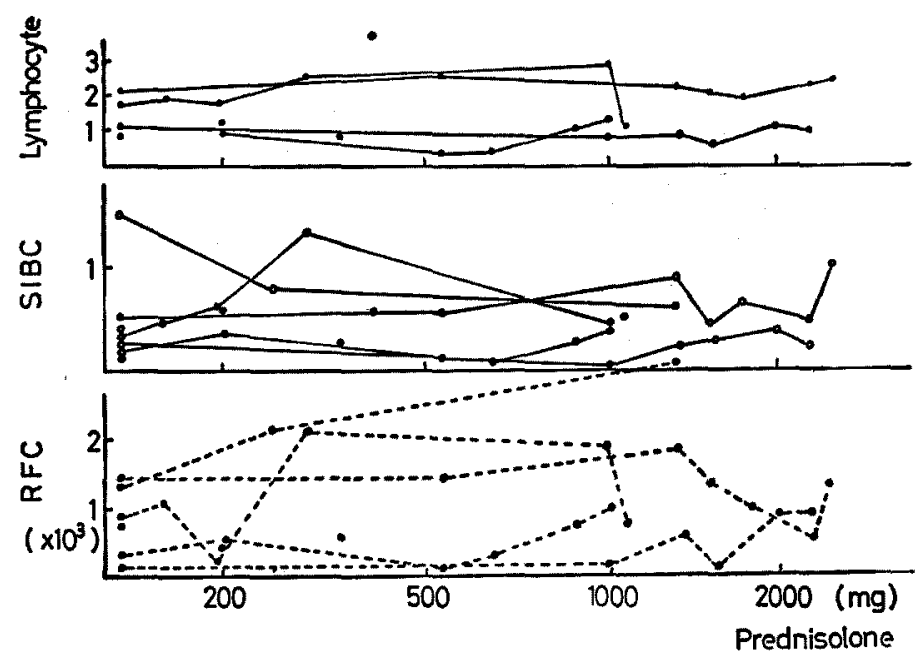

Fig. 5 The effect of accumulative doses of prednisolone on lymphocyte subpopulations.

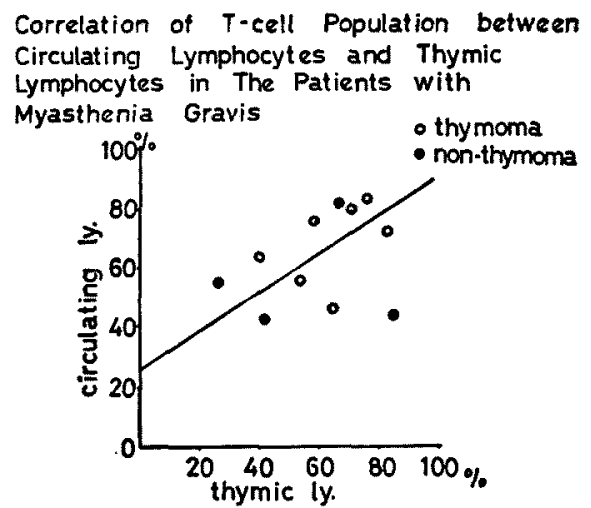

Fig. 6 Correlation of T-cell population between thymic lymphocyte and circulating lymphocyte in the patients with myasthenia gravis.

$(r=0.482)$, but no such correlation was observed for B-cell $(r=0.281)$.

Under the further investigations of lymphocyte subpopulations among the various immunological disorders, T-cells decreased in almost all of them, especially in systemic lupus erythematosus and Hashimoto's disease $(0.001<\mathrm{p}<0.01)$ and progressive systemic sclerosis $(0.01<\mathrm{p}<0.02)$ (Fig. 7). The lymphocyte 


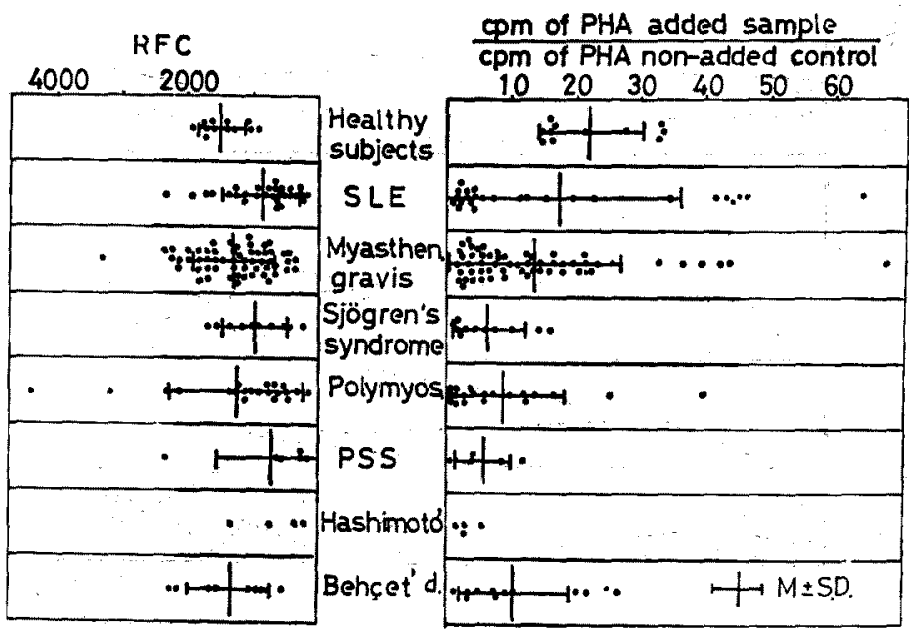

Fig. 7 This figure shows individual values as well as mean \pm standard deviation of peripheral T-cell and PHA-S.I. among the various diseases of patients studied. The means and 1 SD for the group studied were; healthy subjects $1503 \pm 342$ $(\mathrm{N}=11), 2211 \pm 820(11)$; systemic lupus erythematosus $862 \pm$ $577(26), 1724 \pm 1888(26)$; myasthenia gravis $1297 \pm 615(56)$,

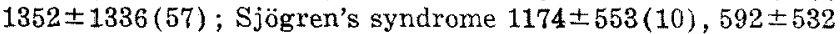
(11) ; polymyositis $1118 \pm 908(30), 817 \pm 996(29)$; progressive systemic sclerosis $712 \pm 836(6), 585 \pm 430(6)$; Hashimoto's disease $658 \pm 507(4), 300 \pm 151(4)$ and Behçet's disease $1329 \pm 616(9), 1043 \pm 842(11)$, for T-cell and PHA-S.I. respectively.

response to PHA-P stimulation reduced significantly in the patients with Sjögren's syndrome and polymyositis $(p<0.001)$, progressive systemic sclerosis, Hashimoto's disease and Behçet's disease $(0.001<\mathrm{p}<0.01)$, and myasthenia gravis as total $(0.02<\mathrm{p}<0.05)$. The $B$-cell percentage decreased in the patients with progressive systemic sclerosis $(0.001<p<0.01)$. Statistical significance was not obtained as total either B-cell or pokeweed mitogen responsiveness.

Good correlation was obtained between myasthenic symptomes and T-cells (mild $>$ moderate $>$ serious), B-cells (mild $<$ moderate $\ll$ serious), PHA-S.I. (mild $>$ moderate $>$ serious), PWM-S.I. (mild $=$ moderate $>$ serious) and serum $\gamma$-globulin (mild $=$ moderate<serious) (Fig. 8).

The percentages of $\mathrm{T}$-cell and B-cell in the bone marrow lymphocytes were $14.8 \%$ and $17.2 \%$ in healthy subjects, $25.3 \%$ and $30.2 \%$ in myasthenic patients, $24.4 \%$ and $21.6 \%$ in aplastic anemia, and $10.8 \%$ and $49.0 \%$ in the patients with 


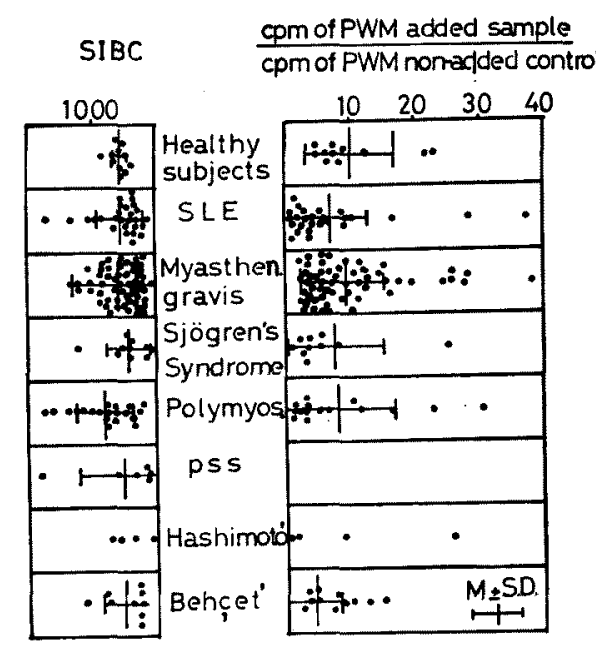

Fig. 8 This figure shows individual values as well as mean \pm standard deviation of peripheral B-cell and PWM-S.I. among the various diseases of patients studied. The means and 1 SD for the groups studied were; healthy subjects $584 \pm 133$ (11), $1013 \pm 666(11)$; systemic lupus erythematosus $547 \pm 368(26), 687 \pm 857(26)$; myasthenia gravis $616 \pm 683(16), \quad 944 \pm 708(57)$; Sjögren's syndrome $465 \pm 304(10), \quad 777 \pm 749$ (10) ; polymyositis $653 \pm 422(29), 709 \pm 762(24)$; progressive systemic sclerosis $524 \pm 654(6)$, not determined; Hashimoto's disease 425 $\pm 292(4)$, $936 \pm 1161(4)$; and Behçet's disease $487 \pm 313$ (9), $436 \pm 409$ (11), for B-cell and PWM-S.I. respectively.

lung cancer, respectively. No correlations were obtained between the bone marrow lymphocytes and circulating lymphocytes indicating fewere T-cell in the bone marrow lymphocytes than the circulating lymphocytes. The lymphocytes obtained from the peritoneal lymphnode had $8.6 \%$ T-cell and $49.6 \%$ B-cell. The lymphocytes in spleen consisted in $24.0 \%$ T-cell and $37.6 \%$ B-cell as well as the lymphocytes in tonsil divided into $6 \% \mathrm{~T}$-cell and $43.4 \%$ B-cell. The cord blood lymphocytes have shown $50.0 \%$ T-cell and $13.0 \%$ B-cell.

Lymphocyte subpopulations in the tissue were identified with EAC and E. The EAC bound on lymphocytes were observed in the area of germinal center including lymph follicles (Photo 1) in high density, and in hilar region in lower density, on the cryosections of human abdominal lymphnode obtained from the 


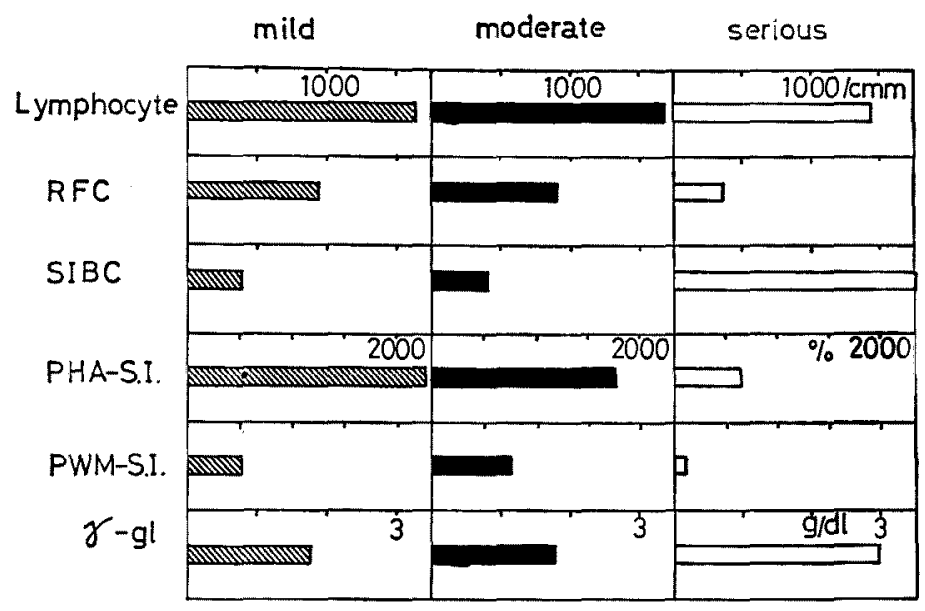

Fig. 9 The patients with systemic lupus erythematosus were divided into three groups according to their clinical activities; mild, moderate and serious groups. Good correlations were obtained between the severity and the lymphocytes function of SLE patients including the lymphocyte subpopulations and their mitogenic reactivities.

patients with gastric ulcer. The $\mathrm{E}$ distributed in the paracortical area in the same tissue. In the tonsil the EAC overlayed in the lymphoid nodules (Photo 2) as well as the lymphocytes in the crypt (Photo 3 ), in contrast a few $\mathrm{E}$ scattered among the lymphoid nodules.

The thyroid glands obtained from Hashimoto's disease had EAC-bound lymphocytes in the infiltrated lymph follicles (Photo 4) and in coloidal follicle, being observed E-bound lymphocyte around the destructed follicular epithelium (Photo 5).

The myasthenic thymus obtained from type III, 47 year old male, had EACbound lymphocytes in the lymph follicle (Photo 6) in non-thymomatous tissue, though E-bound lymphocytes surround the lymph follicle (Photo 7).

The skeletal muscle (Photo 8) obtained from 27 year old female at the thymectomy had lymphorrhage binding EAC with few contamination of E-bound lymphocytes. It was attractive findings that this muscle fibers (Photo 9) bound the EAC around the muscle membrane, being blocked this binding with human serum including complement (Photo 10) as well as anti-human IgG rabbit serum, but being not blocked with fetal calf serum. The membrane immunofluorescent method proved the existence of the membrane bound immunoglobulin, as IgG rather than $\operatorname{IgM}$ or $\operatorname{IgA}$, on the surface of infiltrated lymphocytes and muscle 
membranes. The specimens of kidney obtained from 23 year old male suffered from chronic glomerulonephritis showed the bindings of neither EAC nor E, though aggregated $\mathrm{IgG}$ deposit were demonstrated in glomeruli using the membrane immunofluorescence on non-fixed cryosections and not demonstrated any fluorescence using immunofluorescence technique on alcohol fixed cryosections.

\section{DISCUSSION}

The thymus abnormalities, including the development of thymoma and the germinal centers in the hyperplastic thymic tissue, ${ }^{21}$ and the effect of thymectomy on the myasthenic symptoms ${ }^{17}$ incite the idea of T-cell deficiency in the myasthenic patients as their pathogenesis.

There has been recent evidence from cell-migration inhibition assays suggesting that cell-mediated immune reactivity to muscle components may be demonstrable in both peripheral blood ${ }^{3}$ and thymic cells ${ }^{2}$ of patients with myasthenia.

Abdou et al. $(1974)^{1}$ recently published the evidence for altered thymic cell populations indicating that an increased number of B-cells, carrying predominantly $\mathrm{IgM}$ receptors, and vigorous response to pokeweed mitogen were characteristic in thymic-cell populations from the myasthenic patients as compared to that in the control cardiac-surgery patients. They also mentioned that, in mixed leukocyte reactions, thymic cells from the subjects with hyperplasia were capable of stimulating autologous peripheral blood lymphocytes without any pathogenic implications.

Our findings on myasthenic lymphocytes indicated that $\mathrm{T}$ - and B-cells in the circulating lymphocytes were decreasing in the non-thymectomized patients in combination with a lower responsiveness to PHA-P and pokeweed mitogen and with reduced incorporation of ${ }^{3} \mathrm{H}$-thymidine in soloculture suggesting the evidence of decreased cellular immunity.

However, the relative percentages and numbers of T- and B-cells, responsiveness to mitogens in vitro and the circulating lymphocytes counts may vary considerably in different patients in different situations such as in pre- or postthymectomy, in existence of thymoma or non-thymomatous thymus, in administration of immunosuppressants or not, and in crisis or not. And variations in some extent occur in the same patient at different points in time.

The T-cell in peripheral blood decreased considerably in the thymomatous myasthenia than in the non-thymomatous myasthenia of non-thymectomized patients, being correlated well with T-cell percentage in thymic lymphocytes operated. An increase of these $\mathrm{T}$-cell in peripheral blood to a normal range was 
observed after thymectomy in both non-thymomatous and thymomatous patients. The B-cell as well as the circulating lymphocytes counts are decreased more in the non-thymomatous patients than in the thymomatous patients before thymectomy. Through the thymectomy the B-cell in the non-thymomatous patients increased significantly, though it remained under a normal range. The circulating lymphocytes of this group rather reduced their number after the thymectomy. Among the thymomatous patients, B-cell as well as $\mathrm{T}$-cell and the circulating lymphocyte counts became normalized in their number and percentage.

These lymphocytes, i.e. both T- and B-cells, of either the thymomatous or the non-thymomatous patients have lower activities to synthesize DNA in vitro than lymphocytes of healthy individual. The response to PHA-P or pokeweed mitogen reduced, too. A grade of reduction of responsiveness of myasthenic lymphocytes to PHA-P is severer than to pokeweed mitogen. The response of lymphocytes to PHA-P stimulation is considered to be more specific to T-cell than B-cell, while pokeweed mitogen stimulates both B- and T-lymphocytes. ${ }^{12}$ The thymectomy improved these lesions of circulating lymphocytes in vitro, especially of T-cell, to a certain extent.

These correlations suggest that profound abnormalities, in number per $\mathrm{cmm}$ and its function of T-cell population, are characteristic in myasthenic patients. The thymus is considered to be the center of immune surveillance. ${ }^{9}$ In fact, the thymus of myasthenia gravis has a higher percentage of B-cell population which hardly found in the normal thymus because of the thymus-blood barrier. The B-cell in the myasthenic thymus locates in the lymph follicle including germinal center. The formation of lymph follicle in the thymus seems to be more specific in myasthenia gravis although many other autoimmune diseases are showing the same abnormalities. ${ }^{21}$ The extirpation of thymoma results in normalization of $\mathrm{T}$ - and B-cell numbers in spite of the extirpation of non-thymomatous thymus which induced lymphopenia with residual B-cell deficiency. This might be not simply depending on the deficit of lymphocyte stimulating hormone ${ }^{16}$ but depending on the disturbance of immune surveillance. This idea is supported by further analysis concerning the effects of thymectomy and of immunosuppressants on myasthenic symptoms which were recovered through the normalization of $\mathrm{T}$ - and B-cell populations, being well related with the severity of clinical signs.

The lymphocytes in the skeletal muscle obtained from myasthenia gravis were revealed to be consisted of B-cell. Our previous report concerning the fine structures of muscle membrane using a freeze-etched method made abnormal deposits on outer surface of skeletal muscle and deformity of T-system openings ${ }^{6}$ clear. This deposits on the outer surface of muscle membrane have been confirmed as immune complex deriving from anti-muscle membrane antibody ${ }^{4,5}$ and 
membrane glycoroteins. ${ }^{23}$ The anti-motor endplate antibody ${ }^{8}$ in the sera of myasthenic patients seems to be responsible for blocking neuromuscular junctions. The T-cell could recognize these minor immune complex on the surface of skeletal muscle in vivo as a not-self antigen. This committed or memory T-cell in the circulating lymphocytes may transmit further information to B-cells as well as non-committed T-cells in the regional lymphnode and in the thymus. On the other hand, the local immune reactions on the muscle surface might produce the chemical mediators including histamine and slow reacting substance derived from local mast cells and from converged neutrophils. The chemical mediators induce a rise of the permeability of the blood vessels, especially in the thymus. The cooperation of the memory $T$-cell and a rise of the permeability of the capillary wall in the thymus might be followed by the invasion of B-cells, resulting in forming a lymph follicle and germinal center in the thymus according to resistance of the individuals.

Autoimmune phenomena among the thymus, regional lymphnode, lymphorrage in the muscle and the surface immune deposits of muscle membrane, and the motor endplate will be maintained continuously with expansion of target organs. The thymoma might be considered to be a product of blastformation in vivo from thymic lymphocytes or thymic epithelial reticulum cells, being stimulated by the immune complex or by the anti-membrane antibody which includes both anti-muscle membrane antibody and anti-motor endplate antibody, and in which one could demonstrate the binding capacities to the membrane surface over the organ specificity and over the species specificity under the common chemical compositions of biomembranes.

The lymphocytes of various immune disorders other than myasthenia gravis could demonstrate enough abnormalities in T-cell populations including PHA-P responsiveness. The $\mathrm{B}$-cell population and pokeweed mitogen responsiveness had great variation depending on the patient situation. One of this evidence was indicated in the good correlation between clinical activities of systemic lupus erythematosus and T- and B-cells, lymphocytes in peripheral blood, PHA-P and pokeweed mitogen reactivities of lymphocytes in vitro, and serum $\gamma$-globulin levels. The surface receptors of lymphocytes could be demonstrated electronmicroscopically under the immunofreeze-etched method. ${ }^{18,22}$ This receptor sites can be modified by the anti-membrane antibody, ${ }^{23}$ resulting in a decrease of responsiveness to non-specific mitogens and finally a immune cytolysis.

Tissue localization of two populations of lymphocytes distinguished by membrane receptors was studied by Silveira et al. (1972) ${ }^{19}$ using E and EAC on the human lymphoid organs, and by Gutman and Weissman (1972) ${ }^{11}$ using immunofluorescent staining on the lymphoid rogans of mice, independently. Clinical ap- 
plication of this methodology can be found only in the salivary glands in the patients with Sjögren's syndrome. Talal et al. (1974) ${ }^{20}$ indicated that striking accumulations of T-cells mixed clusters of presumed B-cells were present in tissue lesions with Sjögren's syndrome using an indirect immunofuorescent method with rabbit anti-human thymocyte antiserum and conjugated goat anti-rabbit IgG. The B-cells were identified with a conventional histologic grading using a "focus scoring method" in the same slide of T-cells which were counted by fluorescent techniques. On the other hand. Chused et al. (1974) ${ }^{10}$ demonstrated the B-cell infiltration into the salivary glands of Sjögren's syndrome, using $\mathrm{E}$ for identifying T-cell, 19S EAC for B-cell, 7S EA for monocyte and 19S EA for control. Fundamental study of $\mathrm{T}$ - and B-cell identifications in the present paper was performed using lymphnode, thymus and tonsil. A large portion of infiltrating lymphocytes into the thyroid and skeletal muscle was identified as EAC-bound lymphocytes or B-cells. Among them a few T-cells were scattered. Of interesting, muscle surface of myasthenic patients was proved to be bound to the EAC and not to the $\mathrm{E}$, based on the fact that this binding was blocked by either fresh human serum and anti-human IgG serum. This indicates that the surface might bear complement receptor or immune complex. Fetal calf serum could not block the EAC binding on the muscle membrane surface. The pathognomonic significance of these abnormal $\mathrm{T}$ - and B-cells in tissue remains open to further investigation as to whether they are acting destructively or constructively.

\section{CONCLUSION}

Myasthenic lymphocytes were studied in their sub-populations, i.e. T- and B-cells, of skeletal muscle, being combined with the response to PHA-P and pokeweed mitogen in vitro.

Decreased $T$-cell and B-cell number with lower responsiveness to mitogens, especially to PHA-P, was characteristic in myasthenia gravis indicating the abnormality of T-cell function. The extirpation of the thymus, either thymoma and/or non-thymomatous thymus with "B-cell origin lymph follicle" as well as the administration of immunosuppressants induced the normalization of these lymphocyte deficiency.

Including the lymphocytes of the patients with systemic lupus erythematosus, these lymphocyte deficiency was in proportion to the severity of clinical symptoms.

Local T- and B-cell identification using $\mathrm{E}$ and $\mathrm{EAC}$ on the cryosections indicated that a major portion of lymphorrhage in the skeletal muscle of myasthenic patients was B-cell. Relationship between myasthenic lymphocytes (i.e. T- and 
B-cell in the peripheral blood, thymic lymphocytes and lymphocytes in local) and humoral antibody, especially anti-muscle membrane and anti-motor endplate antibodies, was discussed as pathogenesis of myasthenia gravis.

\section{ACKNOWLEDGMENTS}

The authors would like to thank Prof. Kiyoshi Hiraki for fruitful discussions. This work was supported by Grant from the Special Disease Division of the Ministry of Healthy and Welfare, and the Grant No. A-977170 from the Ministry of Education of Japan.

\section{REFERENCES}

1. Abdou, N. I., Lisak, R. P., Zweiman, B., Abrahamsohn, I. and Penn, A. S.: The thymus in myasthenia gravis. Evidence for altered cell populations. New Engl. J. Med. 291: 1271,1974

2. Armstrong, R. M., Nowack, R. M. and Falk, R. E.: Thymic lymphocyte function in myasthenia gravis. Neurology 23: 1078, 1973

3. Alpert, L. I., Rule, A., Norio, M., Kott, E., Kornfeld, P. and Osserman, K.E.: Studies in myasthenia gravis: Cellular hypersensitivity to skeletal muscle. Amer. J. Clin. Pathol, 58: 6471972

4. Arimori, S. and Nakata, Y.: On the significance of the anti-muscle and -erythrocyte membrane factors in systemic lupus erythematosus. Europ. J. Clin. Biol. Res. 17: 970,1972

5. Arimori, S. and Nakata, Y.: Membrane protein binding antibody found in various patients of proposed "Membrane disease" Keio J. Med. 21: 147, 1972.

6. Arimori, S. and Tada, S.: Comparison of surface architectures of normal and myasthenic muscles as observed by freeze-etching method. Med. Biol. 88: 335, 1974

7. Arimori, S. and Tada, S.: Anti-muscle membrane antibody and anti-motor endplate antibody found in sera of the patients with myasthenia gravis. Jap. J. Allerg. 23: 696,1974

8. Arimori, S., Tada, S., Kobashi, H., Ichikawa, Y. and Koriyama, K.: Anti-motor endplate antibody and anti-muscle membrane antibody found in serum IgG of the patients with myasthenia gravis. Jap. J. Allerg. 23: 839, 1974

9. Bach, J.-F.: The thymus, key organ in immunity. Presse Med. 3: 571, 1974

10. Chused, T. M., Hardin, J. A., Frank, M. M. and Green, I.: Identification of cells infiltrating the minor salivary glands in patients with Sjögren's syndrome. J. Immunol. 112: 641,1974

11. Gutman, G. A. and Weissman, I. L.: Lymphoid tissue architecture. Experimental analysis of the origin and distribution of T-cells and B-cells. Immunology 23: 465,1972

12. Greaves, M. F., Owen, J. J. T. and Raff, M. C.: T and B lymphocytes. Excerpta Med., N.Y., 1973

13. Harvard, C. W. H.: Progress in myasthenia gravis. Brit. Med. J. 3: 437, 1973

14. Namba, T., Arimori, S. and Grob, D.: Effect on mice of intravenous administration of lymphocytes from normal subjects and from patients with myasthenia gravis. Neurology 19: 462, 1969

15. Namba, T., Arimori, S. and Grob, D.: Lymphocytes of patients with myasthenia gravis. Local effects in rats following intramuscular administration. Arch. Neurol. 21: 285,1969 
16. Osoba, D. and Miller, J. F, A. P.: The lymphoid tissues and immune responses of neonatally thymectomized mice bearing thymic tissues in millipore diffusion chambers. J. Exp. Med. 123: 191, 1966

17. Papatestas, A. E., Alpert, L. I., Osserman, K. E., Osserman, R. S. and Kark, A. E.: Studies in myasthenia gravis: Effects of thymectomy: Results of 185 patients with nonthymomatous and thymomatous myasthenia gravis, 1941-1969. Am. J. Med. 50: 465, 1971

18. Perkins, W. D., Karnovsky, M. J. and Unanue, E. R.: An ultrastructural study of lymphocytes with surface-bound immunoglobulin. J. Exp. Med. 135: 267, 1972

19. Silveira, N. P. A., Mendes, N. F. and Tolnai, M. E. A.: Tissue localization of two populations of human lymphocytes distinguished by membrane receptors. J. Immunol. 108: 1456, 1972

20. Talal, N., Sylvester, R. A., Daniels, T. E., Greenspan, J. S. and Williams, R. C. Jr.: $T$ and $B$ lymphocytes in peripheral blood and tissue lesions in Sjögren's syndrome. J. Clin. Invest. 53: 180, 1974

21. Tamaoki, N., Habu, S. and Kameya, T.: Thymic lymphoid follicles in autoimmune diseases. II. Histological, histochemical and electron microscopic studies. Keio $J$. Med. 20: 57, 1971

22. Unanue, E. R., Karnovsky, M. J. and Engers, H. D.: Ligend-induced movement of lymphocyte membrane macromolecules. III. Relationship between the formation and fate of anti-Ig-surface Ig complexes and cell metabolism. J. Exp. Med. 137: 675,1973

23. Arimori, S.: Antimembrane antibody: Analysis of its reactivity against the cell surface antigens by gel filtrations and freeze-etching method. Acta Haem. Jap. $36: 829,1973$ 


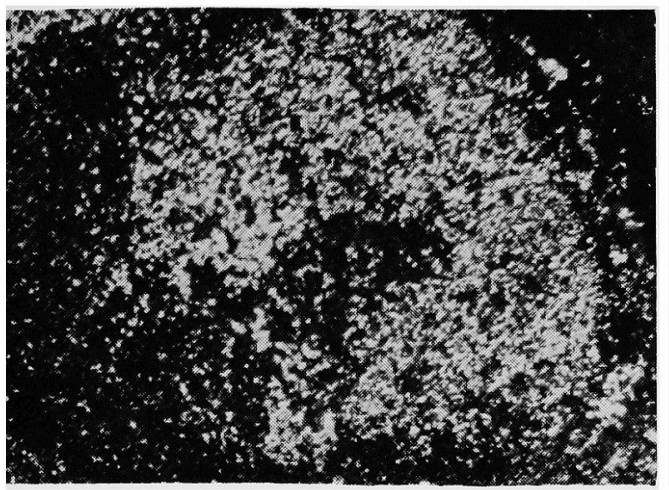

Photo 1

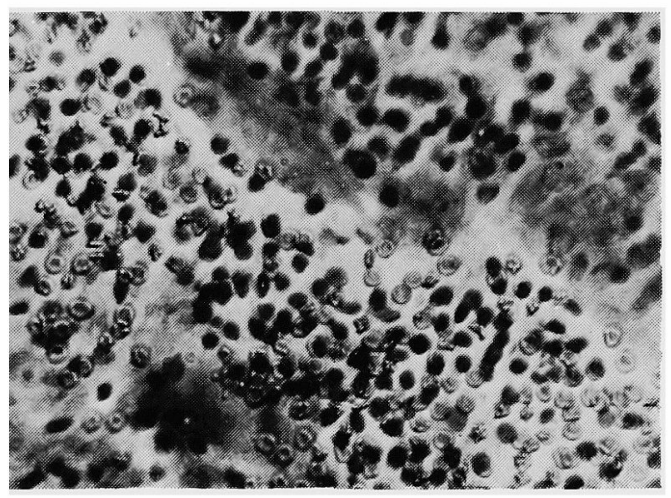

Photo 3

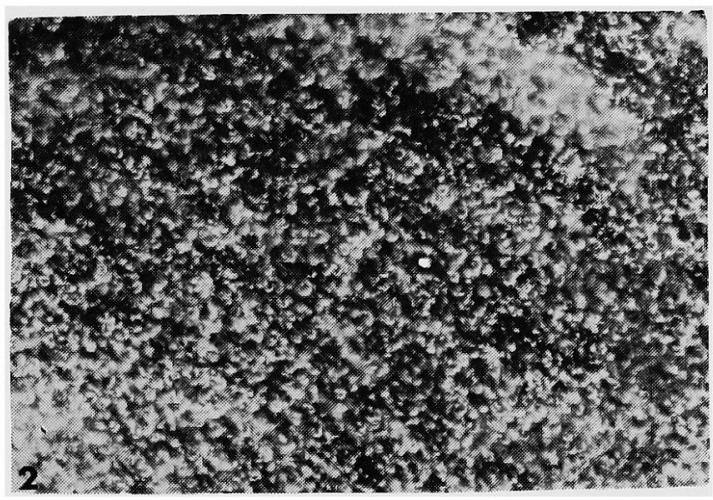

Photo 2

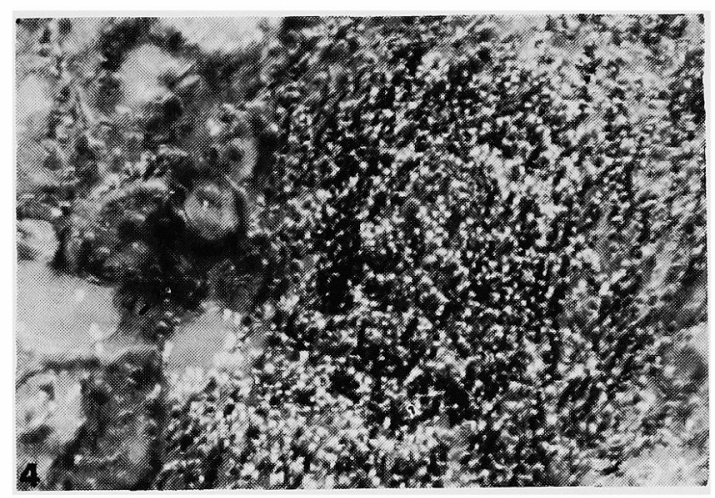

Photo 4

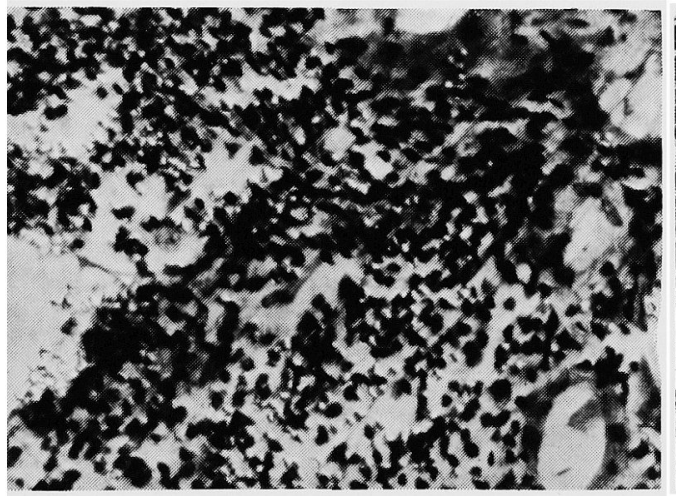

Photo 5

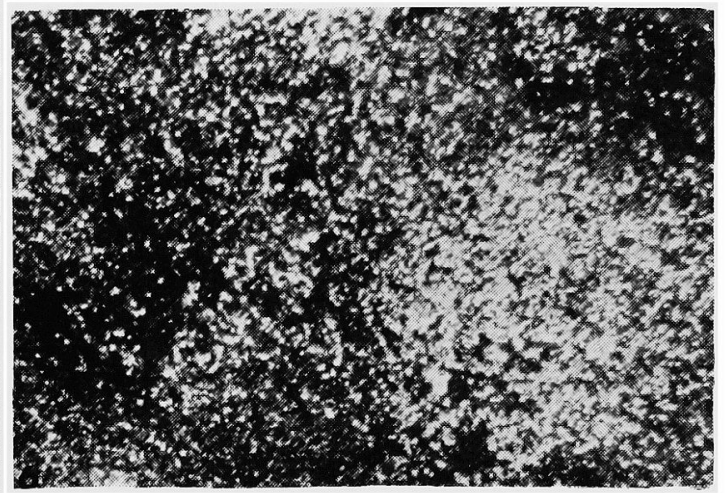

Photo 6 


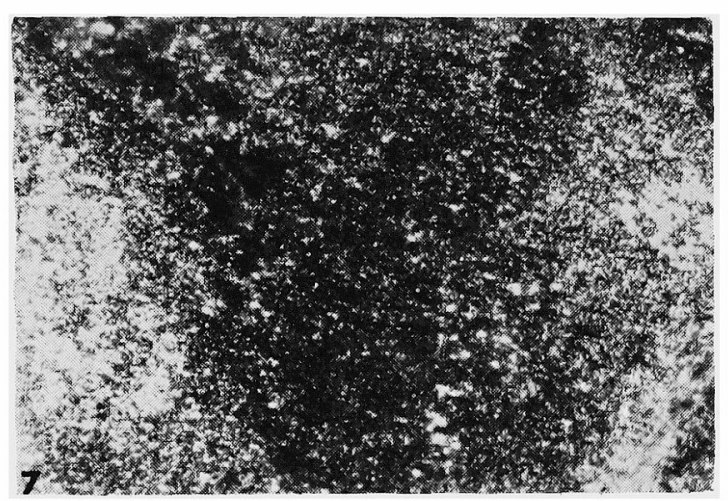

Photo 7

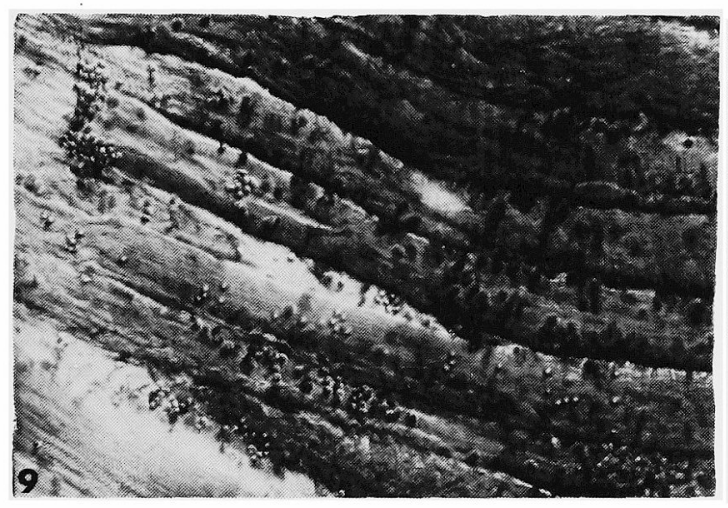

Photo 9

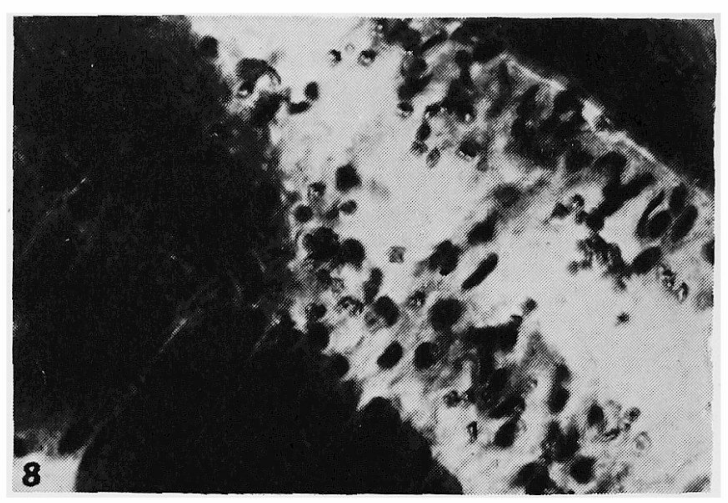

Photo 8

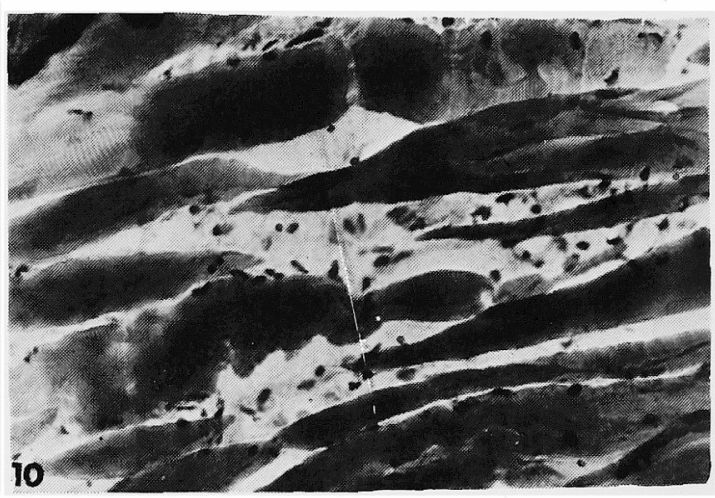

Photo 10

Photo 1 The complement-coated sheep erythrocytes (EAC) bind massively on the lymphocytes in the area of germinal center including lymphfollicle of the lymphnode obtained from the patient with gastric ulcer. $(\times 100)$ The lymphocyte bound EAC is considered to be B-cell.

Photo 2 The lymphocytes in the lymphoid nodule of tonsil were oberlayed with EAC in high density. $(\times 200)$

Photo 3 The EAC adhered also to the lymphocyte in the crypt to tonsil. $(\times 400)$

Photo 4 The infiltrating lymphocytes in the thyroid gland of the patient with Hashimoto's disease compose a lymphfollicle and were covered profusely with EAC. $(\times 100)$

Photo 5 Nonsensitized sheep erythrocytes (E) adhere to the surface of infiltrating lymphocytes around the destructed follicular epithelium of the thyroid gland obtained from the patient with Hashimoto's desease. $(\times 400)$ The lymphocyte bound $\mathrm{E}$ is considered to be T-cell.

Photo 6 The myasthenic thymus obtained from type III, 47 year old male, has EACbound lymphocytes in the lymphfollicle in non-thymomatous tissue. $(\times 200)$

Photo 7 The lymphfollicle is sorrounded by the E-bound lymphocytes in the same tissue of Photo $6 .(\times 100)$

Photo 8 The lymphocyte in a lymphorrhage of skeletal muscle boipsied from the myasthenic patient, fix the EAC on its surface. $(\times 400)$

Photo 9 The muscle membrane of the patient with myasthenia gravis bind the EAC on its surface as cluster formation. $(\times 200)$

Photo 10 The binding of EAC on the surface of myasthenic muscle membrane can be blocked by human complement. $(\times 2000)$ 